\title{
Personality and Management Level: Traits That Differentiate Leadership Levels
}

\author{
Adrian Furnham1,2, John Crump1 \\ ${ }^{1}$ Research Department of Clinical, Educational and Health Psychology, University College London, London, UK \\ ${ }^{2}$ Norwegian Business School (BI), Nydalveien, Olso, Norway \\ Email: a.furnham@ucl.ac.uk
}

Received 23 February 2015; accepted 3 April 2015; published 8 April 2015

Copyright (C) 2015 by authors and Scientific Research Publishing Inc.

This work is licensed under the Creative Commons Attribution International License (CC BY).

http://creativecommons.org/licenses/by/4.0/

c) (i) Open Access

\begin{abstract}
Over 5000 senior managers attending a structured assessment centre completed three tests (Revised NEO Personality Inventory, NEO-FFI; the Myers Briggs Type Indicators, MBTI; the Fundamental Interpersonal Relations Orientation, FIRO-B). Given their rank and responsibilities they were categorised as Non-Managers or specialists, Middle Managers and Senior Managers (Manager of Managers or Leaders). Results showed the more Senior Managers tended to be less Neurotic and Agreeable, but more Extraverted and Conscientious. They also had less Wanted Inclusion and more Expressed Control scores on the FIRO-B and tended to be higher on MBTI Intuition and on Thinking (vs Feeling). The results of the discriminant analysis showed two FIRO-B factors (Expressed Control and Wanted Control) and two Big Five (Neuroticism and Extraversion) were best discriminators of managerial seniority. Leaders tended to score high on Expressed Control and Extraversion and low on Wanted Inclusion and Neuroticism. Implications for selection and promotion, as well as limitations of the study are considered.
\end{abstract}

\section{Keywords}

Personality, Management, NEO-FFI, Myers Briggs, FIRO-B

\section{Introduction}

To what extent do personality traits help or hinder promotion? Do the people in more senior positions across a wide range of organisations have a different profile from those lower down in the organisation? What traits are associated with those who occupy senior management roles? Do those traits which relate to leadership emergence also related to leadership effectiveness? There is a growing interest in personality trait correlates and predictors of individual and organisational performance, satisfaction and derailment (Judge, Bono, \& Locke, 2000; 
Judge, Higgins, Thoreson, \& Barrick, 1999; Hogan \& Hogan, 1997, 2001; Salgado, 1997). There have also been many studies on the relationship between personality and leadership, so much that a widely cited meta-analysis has been done (Arvey, Rotundo, Johnson, Zhang, \& McGue, 2006; Judge, Bono, Ilies, \& Gerhert, 2002). There are various attempts to describe the skills and factors involved junior, middle and upper management positions (Tornow \& Pinto, 1976).

Many people have speculated about which traits (and disorders) are associated with leadership success and failure (Furnham, 2008ab). Ideally this question is best asked by longitudinal research following individuals with known, psychometrically valid, trait scores as they enter an organisation and then track and trace how, where and why they got promoted to senior positions or not. Although there are a few longitudinal studies they have tended not to examine questions of managerial level (Furnham, 2008b). However what longitudinal studies have tended to show is the stability of personality over time. This suggests that people, once adults, do not change much and that traits there-fore influence promotability (Costa \& McCrae, 2004). If there was robust evidence, and an explanation for, the fact that a managers personality changed over time specifically as a function of taking on leadership roles it would be impossible to do valid cross-sectional studies on trait predictors of organisational position. However none such exists and there are no models or theories that propose normal adult personality changes much as a function of taking on leadership roles. That is, temperament and traits are fixed, though people can and do change behaviours and learn skills over time. Personality and cognitive ability along with specific motivations determine skill, and knowledge as well as the desire to get promoted (Hogan, 2006).

There have however been a number of cross-sectional studies that have investigated organisational level differences in personality and intelligence. Two studies are relevant to this study using a related data set. Furnham, Crump and Chamorro-Premuzic (2007) examined individual difference factors related to management level: intelligence, personality traits and personality disorders. They found contradictory results for the two intelligence tests that they used: One indicated senior managers the least intelligent, others the most intelligent. The results for personality were clearer. Senior managers had higher Expressed and Wanted Control than middle managers on the FIRO-B (Schutz, 1958, 1992). They also expressed, but did not want, more Inclusion than middle managers. With respect to the personality disorders as measured by the Hogan Developmental Survey (Hogan \& Hogan, 1997) senior managers tended to be less diligent and dutiful than junior managers.

Moutafi, Furnham and Crump (2007) looked at sex, age, Big five, and Big Four (i.e. MBTI) correlates of managerial level in 900 managers. They found managerial level was significantly correlated with NEO-PI Neuroticism, Extraversion, Conscientiousness, MBTI Introversion, Sensing, Intuition, Thinking. They also looked at a facet analysis which showed the following: the more senior the manager the more he/she was likely to be achievement striving, dutiful, competent, orderly, assertive, active and gregarious and the less likely they were to be anxious, depression prone, self-conscious and vulnerable.

Moutafi et al. (2007) was based on 900 man-agers from various backgrounds. This study builds upon the above study using a new but related data set collected in the same way by the same consultancy. The tests used were used mainly for assessment, development and increasing awareness. However, this study differs from the above two related studies in two ways. First, it uses a very large number of managers, many organisational leaders, much higher than in the above studies with groups over 4000 for two of the three measures. Second it uses a discriminant analysis, to examine the effects of three tests scores simultaneously to differentiate three management groups. Hypotheses from each of the three tests used will be considered separately.

\subsection{The Big Five (NEO-PI)}

The use of the Big Five measures has meant many studies have examined personality correlates of a wide set of behaviours from absenteeism to sales (see Furnham 2008 for review). Various studies have demonstrated that of the Big Five traits, Conscientiousness and Neuroticism are the factors that are most consistently correlated with job performance (Furnham, 2008). Conscientiousness has been found to positively correlate with salary (Barrack \& Mount, 1991; Orpen, 1983), with promotions (Howard \& Bray, 1994; Jones \& Whitemore, 1995), with supervisor ratings of job performance in the military (Hough et al., 1990) and with job status (Judge et al, 1999). Neuroticism has been found to be negatively correlated with job performance (Salgado, 1997). Research has shown Neuroticism to be a valid predictor of performance in assessment centre exercises (Spector et al., 2000) and facets of Neuroticism (self-acceptance and self-confidence) have been found to negatively correlate with salary (Harrell, 1969; Rawls \& Rawls, 1968) and occupational status (Melamed, 1996). 
Howard and Howard (2001) suggest from their case study and assessment centre data set that leadership is characterised by low Neuroticism and Agreeableness scores and high Extraversion, Openness and Conscientiousness scores. For them "the natural leader defined in Big Five terms is resilient $(\mathrm{N}-)$; energetic, outgoing, and persuasive $(\mathrm{E}+)$; visionary $\left(\mathrm{O}^{+}\right)$; competitive $\left(\mathrm{A}^{-}\right)$; and dedicated to a goal $(\mathrm{C}+)^{\prime \prime}$ (p. 115).

Extraversion has been found to correlate with salary and job level (Melamed, 1996). Furthermore, dominance and sociability which are facets of Extraversion, have been found to correlate with salary, job title and leadership promotions (Caspi, Elder, \& Bem, 1987; Howard \& Bray, 1994; Rawls \& Rawls, 1968).

Openness and Agreeableness are the trait factors that have not been found to correlate consistently with job performance. Openness has been found to be a valid predictor of training proficiency (Barrick \& Mount, 1991) and of effectiveness (Judge, Bono, \& Locke, 2000). However, as Judge et al. (1999) noted, Openness and Agreeableness have characteristics that could be detrimental for job performance for specific occupations. Indeed, Furnham (2008) has argued that because leaders have to be tough minded and frequently confront negative performance, Disagreeableness is likely to be correlated with seniority. Based on the extant literature was therefore predicted that compared to non and middle managers, senior managers/leaders would be more Extraverted $\left(\mathrm{H}_{1}\right)$ and Conscientious $\left(\mathrm{H}_{2}\right)$ but less Agreeable $\left(\mathrm{H}_{3}\right)$ and Neurotic $\left(\mathrm{H}_{4}\right)$.

\subsection{Fundamental Interpersonal Relations Orientation-Behaviour (FIRO-B)}

This study will also look at personality as measured by FIRO-B scores. Because of its popularity especially with organisational psychologists and management consult-ants in Great Britain and elsewhere in the English speaking world it has been standardised for use in Great Britain (Dancer \& Woods, 2006; Leigh et al., 1997). Its psychometric qualities have recently been assessed (Furnham, 2008a).

The FIRO theory identifies three dimensions concerned with an individual's typical interpersonal behaviour (Schutz, 1958, 1992). The measure however appears to be unique in that a person received two scores for every dimension: the extent to which a person ex-presses, manifests or shows a particular behaviour (that is the extent to which it is overt and observable) and the extent to which a person wants from other people with respect to a particular class of behaviours. The measure therefore allows for the possibility of measuring a difference or disparity score. The theory asserts that high difference scores lead to conflict for each of the three dimensions. The measure is theoretically based on people's fear of rejection, failure and intimacy: the three dimensions measured by this test. The theory asserts that striving for compatibility in interactions, leads to the development of three primary interpersonal needs that must be satisfied.

The first dimension or trait in the test is the need for Inclusion, which is a need to maintain a relationship with other people, to be included and include others in their activities. Individuals seek to belong to a group, but at the same time they want to be left alone. Therefore individuals differ in their relative need strength on two aspects of the need for inclusion: the need to include others, or Expressed Inclusion (EI), and the need to be included by others or Wanted Inclusion (WI).

A second fundamental interpersonal need, according to Schutz (1958) is a need for Control: a need to maintain a satisfactory balance of power and influence in relationships. All individuals supposedly need to exert control or direction over other people, while also remaining independent from them. They also feel the need to be controlled, directed or structured by others, but at the same time to maintain their freedom and personal discretion. Individual differences arise in the need to control others, (Expressed Control: EC) and the need to be controlled by others (Wanted Control: WC).

A third need, according to the model, relates to Affection, or the need to form close personal relationships with others. All individuals need to form close, personal relationships with other people, but at the same time want to avoid becoming overcommitted or smothered by them. There is a trade-off between high affiliate needs and high independence needs. Individuals therefore vary in their needs for Expressed Affection (EA), towards other people and for Wanted Affection (WA) to be expressed towards them.

One recent study looked at assessed leadership capability, managerial level and the FIRO-B. Ahmetoglu, Chamorro-Premuzic and Furnham (2010) found Ex-pressed Control was the only significant correlate of managerial level but that Expressed Inclusion, Control and Affection were all significantly correlated with assessment centre ratings of Leadership. The limited extant literature seems to imply that leadership would be correlated with high Expressed Inclusion and Control. Hence it was predicted that compared to middle and non managers, business leaders would score higher on Ex-pressed Inclusion (H5) and Control (H6) but lower on Wanted Inclu- 
sion (H7) and Control (H8).

\subsection{Myers Briggs Type Indicator (MBTI)}

Researchers have also looked, though to a much lesser extent, at the relationships between job performance and the four bipolar personality dimensions de-rived by the Myers Briggs Type Indicator (MBTI) (extraversionintroversion, sensing-intuition, thinking-feeling, judging-perceiving) (Myers \& McCaulley, 1985), a test based on Jung's theory of personality dimensions. The test however has not been without criticism of its theoretical heritage or psychometric properties (Furnham, 2008).

The Extraversion-Introversion dimension has been found to correlate modestly with self-reported income (Rice \& Lindecamp, 1989). Extraversion-introversion has also been indirectly linked to job performance through job satisfaction, with extraverts being more satisfied than introverts (Rahim, 1981). With respect to the sensing-intuition dimension sending individuals have been found to perform better at innovative projects than intuitive individuals (Henderson \& Nutt, 1980). It has also been proposed, however, that culture could be a moderating factor in the relationship between job performance and Extraversion-Introversion, as well as Sensing-Intuition (Furnham \& Stringfield, 1993). For example Extraversion-Introversion, has been found to positively correlate with teamwork, commitment and potential for European managers, but negatively correlate with decisionmaking and achieving key results for Chinese managers. In addition, Sensing-Intuition has been found to correlate positively with job performance for Chinese managers, but negatively for European managers (Furnham \& Stringfield, 1993).

The judging-perceiving and the thinking-feeling dimensions have also been modestly linked to job performance. Myers (1962) argued that both judging-perceiving and thinking-feeling should be positively correlated with managerial performance. Judging-perceiving has further been indirectly linked to job performance, through job satisfaction, with judging types being more satisfied than perceiving types, irrespective of their occupation (Rahim, 1981). The thinking-feeling dimension has also been found to be linked to success in small retailers (Rice \& Lindecamp, 1989), and it has been suggested that feeling individuals should perform better at jobs requiring innovation compared with thinking individuals (Henderson \& Nutt, 1980). Based on the work of Moutafi, Furnham and Crump (2007) and others it was predicted that compared to middle managers and non-managers, leaders would score higher on Intuition (H9) and Thinking (H10).

This study examines the personality traits of three sets of managers using three tests. Hence it was possible to do a discriminant analysis including all three potentially overlapping tests together. The aim is to predict group membership based on a linear combination of the interval variables. In this study it will show which of the various measures from all three tests are the most powerful predictors of the three groups to which the participants belong. No hypotheses were formulated for these analysis although they may potentially be the most interesting part of the whole study.

\section{Method}

\subsection{Participants}

There were 5425 participants of whom 1418 were female. They ranged in age from 17 to 70 with mean of 43 yrs. The vast majority (76.7\%) were British and $92.9 \%$ were at work. In all $83.8 \%$ had English as a mother tongue. As regards education $22.6 \%$ had up to secondary schooling $6.5 \%$ further education, $43.2 \%$ a degree and the remainder post-graduate education.

\subsection{Measures}

\subsubsection{The Revised NEO Personality Inventory (NEO-PI-R) (Costa \& McCrae, 1992)}

This is a 240-item untimed questionnaire, measuring 30 primary and five super-traits. The super-traits are Neuroticism, Extraversion, Openness, Agreeableness and Conscientiousness. Each item of the test is answered on a five-point Likert scale, the answers ranging from strongly disagree to strongly agree. A considerable amount of research has been conducted on the NEO PI-R demonstrating high levels of both reliability and validity (Furnham, 2008). Internal consistency coefficients reported in the manual for the super-traits range from .86 to 95 . Evidence of construct validity of the NEO PI-R has been demonstrated by correlations with the Personality Assessment Inventory (Young \& Schinka, 2001) and the Personal Characteristics Inventory (Barrick \& Mount, 
1993); and predictive validity of the instrument has been demonstrated against several job performance measures (Costa \& McCrae, 1992).

\subsubsection{FIRO-B (Schutz, 1958)}

This is a 54-item questionnaire: 24 questions are completed on a six-point scale (ranging from "nobody" to "most people") where respondents compare their behaviour preferences and patterns with other people. The remaining questions are completed on a 6-point scale (from "never" to "usually") which describes usual patterns of behaviour. The test manual provides impressive evidence of the reliability of the measure and also evidence of concurrent and predictive validity.

\subsubsection{Myers-Briggs Type Indicator (MBTI) (Myers \& McCaulley, 1985)}

This is a 94-item untimed questionnaire (administration time is $15-25$ minutes), assessing preferences on four bipolar scales: Extraversion-Introversion, Sensing-Intuition, Thinking-Feeling and Judging-Perceiving. Respondents are classified into one of 16 personality types, based on the highest score they receive on each of the four scales. Research on the MBTI has demonstrated that the inventory has a satisfactory level of both reliability and validity (Carlson, 1985; Furnham \& Stringfield, 1993). Cronbach’s alpha reliability coefficients reported in the manual range from .76 to .83 and construct validity has been demonstrated by correlations of the MBTI scales with scales of the California Psychological Inventory and the Minnesota Multiphasic Personality Inventory (Myers \& McCaulley, 1985).

\subsection{Levels of Management}

Three levels of management were considered: Non Managers, Mid-Level Manager and Manager of Man-agers. The latter were called leaders as most were at Di-rector level in their organisation leading often sizeable groups.

\subsection{Procedure}

Participants were tested at Kaisen Consulting and they went through a long established Assessment Centre. Participants came from a wide variety of organizations (public and private, large and small, and from different sectors including banking, communication, manufacturing and transportation) and were tested over a number of years. All testers were thoroughly trained and chartered psychologists. The categorisation of people into the three groups was done by a specific formula based on the size, structure and history of the organisation and was shown to be reliable. It was based on the Hay point method and informed by issues concerning leadership skill requirements (Mumford, Campion, \& Morgeson, 2007). Non managers were not necessarily junior but many in senior technical roles that did not require them to manage others. Candidates were given feedback on their performance after the assessment centre.

\section{Results}

Table 1 shows the analysis of each of the domain (higher order) scales from each of the three questionnaires followed by the results of one way ANCOVAs (with sex controlled for) and post-hoc scheffe tests. The results also show the different number of participants in each group. Not all participants completed all questionnaires though there was a total of 1931 participants who completed all three.

Table 1 shows the three groups differed on four of the big "big five" traits. Leaders were the most Stable, most Extraverted and most Conscientious, but least Agreeable (although not significantly more so than middle managers). This confirms $\mathrm{H} 1$ to $\mathrm{H} 4$.

Table 1 also shows senior managers had the highest Expressed Inclusion and Expressed control scores but the lowest Wanted Inclusion scale. This confirms $\mathrm{H} 5$ to H7. They also had the highest Wanted Control Scale. This confirms H8. A difference score was calculated for each of the three dimensions. The difference on Inclusion showed a significant difference $(\mathrm{F}(1,3487)=13.50, p<.001)$ with Leaders having the highest score and supervisors the lowest. The difference was largest for Con-trol with Middle Managers and Leaders having similar scores but supervisors scores much less $(\mathrm{F}(1,3457)=95.52, p<.001)$. The difference score for Affection was not significant.

The MBTI showed Leaders highest on Thinking (this confirms H9) and Perceiving but midway on Sensing- 
Table 1. Means, Standard Deviations and ANCOVA results for the 3 groups.

\begin{tabular}{|c|c|c|c|c|c|c|c|}
\hline & \multicolumn{2}{|c|}{ Non-Managers } & \multicolumn{2}{|c|}{ Managers } & \multicolumn{2}{|c|}{ Business Leaders } & $\mathrm{F}$ \\
\hline NEO-PI & \multicolumn{2}{|c|}{$N=658$} & \multicolumn{2}{|c|}{$N=1332$} & \multicolumn{2}{|c|}{$N=2015$} & \\
\hline Neuroticism & $69.90^{\mathrm{a}}$ & 21.04 & $66.83^{\mathrm{b}}$ & 19.06 & $62.49^{c}$ & 18.48 & $41.04^{* *}$ \\
\hline Extraversion & $122.33^{\mathrm{a}}$ & 18.48 & $125.58^{\mathrm{b}}$ & 18.45 & $128.77^{\mathrm{c}}$ & 17.65 & $35.13^{* * *}$ \\
\hline Openness & 120.37 & 18.27 & 119.37 & 18.39 & 119.94 & 18.15 & .75 \\
\hline Agreeableness & $120.68^{\mathrm{a}}$ & 16.11 & $117.40^{\mathrm{b}}$ & 15.47 & $116.88^{\mathrm{b}}$ & 15.18 & $15.31^{* *}$ \\
\hline Conscientiousness & $130.38^{\mathrm{a}}$ & 17.96 & $131.52^{\mathrm{a}}$ & 16.95 & $134.76^{\mathrm{b}}$ & 17.18 & $20.88^{*}$ \\
\hline FIRO-B & \multicolumn{2}{|c|}{$\mathrm{N}=743$} & \multicolumn{2}{|c|}{$\mathrm{N}=1473$} & \multicolumn{2}{|c|}{$\mathrm{N}=1322$} & \\
\hline Expressed Inclusion & $4.89^{\mathrm{a}}$ & 1.81 & $5.05^{\mathrm{b}}$ & 1.80 & $5.16^{\mathrm{b}}$ & 1.67 & $5.73^{*}$ \\
\hline Wanted Inclusion & $3.68^{\mathrm{a}}$ & 3.02 & $3.66^{\mathrm{a}}$ & 2.87 & $3.39^{\mathrm{b}}$ & 2.63 & $4.09^{*}$ \\
\hline Expressed Control & $3.72^{\mathrm{a}}$ & 2.59 & $5.25^{\mathrm{b}}$ & 2.47 & $6.08^{\mathrm{c}}$ & 2.09 & $225.41^{* * *}$ \\
\hline Wanted Control & $2.90^{\mathrm{a}}$ & 1.95 & $2.97^{\mathrm{a}}$ & 1.87 & $3.48^{\mathrm{b}}$ & 1.78 & $34.67^{* * * *}$ \\
\hline Expressed Affection & 3.57 & 1.93 & 3.71 & 1.96 & 3.60 & 1.88 & 1.93 \\
\hline Wanted Affection & 4.98 & 1.88 & 4.95 & 1.97 & 4.86 & 1.86 & 1.20 \\
\hline MBTI & \multicolumn{2}{|c|}{$\mathrm{N}=1098$} & \multicolumn{2}{|c|}{$N=2133$} & \multicolumn{2}{|c|}{$\mathrm{N}=2195$} & \\
\hline Extraversion-Introver & 22.36 & 13.48 & 21.85 & 13.56 & 21.84 & 13.84 & .53 \\
\hline Sensing-Intuition & $23.04^{\mathrm{a}}$ & 15.29 & $21.53^{\mathrm{b}}$ & 14.09 & $22.03^{\mathrm{a}}$ & 14.34 & $3.94^{*}$ \\
\hline Thinking-Feeling & $24.33^{\mathrm{a}}$ & 15.74 & $28.56^{\mathrm{b}}$ & 15.93 & $28.94^{\mathrm{b}}$ & 15.70 & $33.04^{* * * *}$ \\
\hline Judging-Perceiving & $23.97^{\mathrm{a}}$ & 14.82 & $23.11^{\mathrm{a}}$ & 14.93 & $22.64^{\mathrm{b}}$ & 14.64 & $3.07^{*}$ \\
\hline
\end{tabular}

Means with different superscripts are significantly different at $p<.05$ based on Scheffe post-hoc comparisons. ${ }^{* * *} p<.001,{ }^{* *} p<.05,{ }^{*} p<.05$.

Intuitive compared to the other two groups, which does not fully confirm H9.

Table 2 shows a similar analysis for the 30 facets. In all, 24 out of 30 (or $80 \%$ ) showed significant differences between the three groups. These were consistent. Thus Leaders showed them-selves to be the lowest scorers on five of the six Neuroticism facets, particularly Anxiety, Depression, Self-consciousness and Vulnerability. Similarly five of the six analyses for Extraversion were significant. Leaders were highest on Gregariousness, Assertiveness, Activity and Positive Emotions.

Only three of the six ANCOVAs for the six Openness facets were significant. However all six were significant for the dominance of Agreeableness. Leaders scored highest on Trust but lowest on Tender-minded. On the four other facets they were similar to Middle Managers but different from Non-Managers being less straightforward, Altruistic, Compliant and Modest. The pattern at the facet level thus confirmed the findings at the domain level and gave further support to the first and four hypotheses. Four of the six Conscientiousness facets showed consistent significant results. Leaders had highest scores on Achievement Striving, Competence, Dutifulness and Self Discipline.

\section{Discriminant Analysis}

Discriminant function analysis is used to decide which variables best determine the extent to which people belong to particular groups.

First all 15 variable (5 Big Five, 6 FIRO-B, 4 MBTI) were placed in the discriminant analysis attempting to find which best differentiates between the three groups. The results are shown in Table 3 . Two dimensions of the FIRO, one from the NEO-PI and one from the MBTI were most differentiating. Leaders had high Expressed Control, little Wanted Inclusion and tended to be Extraverted and Perceiving.

The discriminant analysis was repeated but this time using only the two more senior groups (Middle and Senior Managers). The results were similar but not identical. In that analysis which was significant (Eigen- 
Table 2. ANCOVA results with scheffe post-hoc tests for the 30 facets of the NEO-PI-R across the three groups.

\begin{tabular}{|c|c|c|c|c|c|c|c|c|}
\hline & & \multicolumn{2}{|c|}{ Non-Manager } & \multicolumn{2}{|c|}{ Middle Manager } & \multicolumn{2}{|c|}{ Leader } & \\
\hline & \multirow[t]{2}{*}{ NEO-PIR } & \multicolumn{2}{|c|}{$\mathrm{N}=644$} & \multicolumn{2}{|c|}{$N=1316$} & \multicolumn{2}{|c|}{$N=1983$} & \multirow[b]{2}{*}{$\mathrm{F}$} \\
\hline & & $\mathrm{X}$ & SD & $\mathrm{X}$ & SD & $\mathrm{X}$ & SD & \\
\hline N1 & Anxiety & $13.55^{\mathrm{a}}$ & 5.31 & $12.68^{\mathrm{a}}$ & 5.03 & $11.54^{\mathrm{a}}$ & 4.96 & $34.27^{* * *}$ \\
\hline N2 & Anger/Hostility & $10.43^{\mathrm{a}}$ & 4.65 & $10.46^{\mathrm{ab}}$ & 4.57 & $9.97^{\mathrm{b}}$ & 4.51 & $3.23^{*}$ \\
\hline N3 & Depression & $10.67^{\mathrm{a}}$ & 5.09 & $10.01^{\mathrm{b}}$ & 4.69 & $8.97^{\mathrm{c}}$ & 4.39 & $32.75^{* * *}$ \\
\hline N4 & Self-Consciousness & $12.67^{\mathrm{a}}$ & 4.39 & $12.10^{\mathrm{b}}$ & 4.30 & $11.37^{\mathrm{c}}$ & 4.04 & $22.54^{* * *}$ \\
\hline N5 & Impulsivity & 14.77 & 4.56 & 14.87 & 4.37 & 14.59 & 4.29 & .51 \\
\hline N6 & Vulnerability & $7.63^{\mathrm{a}}$ & 3.81 & $6.89^{\mathrm{b}}$ & 3.31 & $6.10^{\mathrm{c}}$ & 3.26 & $42.57^{* * *}$ \\
\hline E1 & Warmth & 23.50 & 3.81 & 23.40 & 3.95 & 23.51 & 3.91 & $4.16^{*}$ \\
\hline E2 & Gregariousness & $19.29^{\mathrm{a}}$ & 4.61 & $19.69^{\mathrm{ab}}$ & 4.63 & $20.19^{b}$ & 4.60 & $15.56^{* * *}$ \\
\hline E3 & Assertiveness & $18.54^{\mathrm{a}}$ & 4.85 & $20.32^{\mathrm{b}}$ & 4.64 & $21.69^{c}$ & 3.97 & $131.55^{* * *}$ \\
\hline E4 & Activity & $20.20^{\mathrm{a}}$ & 4.34 & $21.25^{\mathrm{b}}$ & 4.15 & $22.38^{\mathrm{c}}$ & 3.95 & $93.95^{* * *}$ \\
\hline E5 & Excitement Seeking & 18.27 & 4.56 & 18.72 & 4.59 & 18.67 & 4.30 & 1.76 \\
\hline E6 & Positive Emotions & 22.29 & 4.39 & 22.08 & 4.68 & 22.45 & 4.41 & $6.71^{* * *}$ \\
\hline $\mathrm{O} 1$ & Fantasy & 16.68 & 4.75 & 16.71 & 4.81 & 16.74 & 4.73 & 1.31 \\
\hline $\mathrm{O} 2$ & Aesthetics & 17.62 & 5.77 & 17.42 & 5.91 & 17.43 & 5.99 & 1.08 \\
\hline $\mathrm{O} 3$ & Feelings & 21.69 & 4.19 & 21.48 & 4.15 & 22.74 & 4.18 & $7.61^{* *}$ \\
\hline $\mathrm{O} 4$ & Actions & 19.92 & 4.16 & 19.91 & 4.23 & 20.04 & 4.12 & $4.03^{* *}$ \\
\hline O5 & Ideas & 20.59 & 5.29 & 20.28 & 5.15 & 20.14 & 5.26 & 1.64 \\
\hline O6 & Values & 23.59 & 3.62 & 23.53 & 3.53 & 23.86 & 3.25 & $6.03^{* *}$ \\
\hline A1 & Trust & $20.81^{\mathrm{a}}$ & 4.21 & $21.39^{\mathrm{b}}$ & 4.12 & $22.27^{\mathrm{c}}$ & 3.91 & $43.42^{* * * *}$ \\
\hline A2 & Straightforwardness & $19.05^{\mathrm{a}}$ & 4.41 & $18.19^{\mathrm{ab}}$ & 4.48 & $17.95^{\mathrm{b}}$ & 4.36 & $12.38^{* * *}$ \\
\hline A3 & Altruism & $24.07 a$ & 3.43 & $23.50^{\mathrm{b}}$ & 3.46 & $23.20^{\mathrm{b}}$ & 3.51 & $8.42^{* * *}$ \\
\hline A4 & Compliance & $18.63^{\mathrm{a}}$ & 4.06 & $18.00^{\mathrm{a}}$ & 4.07 & $17.68^{\mathrm{b}}$ & 3.91 & $12.93^{* * *}$ \\
\hline A5 & Modesty & $17.96^{\mathrm{a}}$ & 4.57 & $16.99^{\mathrm{b}}$ & 4.65 & $16.73^{\mathrm{b}}$ & 4.51 & $13.38^{* * *}$ \\
\hline A6 & Tender-mindedness & $20.12^{\mathrm{a}}$ & 3.55 & $19.41^{\mathrm{b}}$ & 3.41 & $18.94^{c}$ & 3.40 & $24.89^{* * *}$ \\
\hline C1 & Competence & $23.44^{\mathrm{a}}$ & 3.37 & $23.81^{\mathrm{a}}$ & $3.15^{\mathrm{a}}$ & $24.38^{\mathrm{b}}$ & 3.16 & $22.06^{* * *}$ \\
\hline $\mathrm{C} 2$ & Order & 19.08 & 4.41 & 18.75 & 4.47 & 18.93 & 4.56 & 1.34 \\
\hline C3 & Dutifulness & $24.38^{\mathrm{a}}$ & 3.60 & $24.33^{\mathrm{a}}$ & 3.56 & $25.13^{\mathrm{b}}$ & 3.47 & $21.53^{* * *}$ \\
\hline $\mathrm{C} 4$ & Achievement Striving & $21.79^{\mathrm{a}}$ & 4.01 & $22.60^{\mathrm{b}}$ & 4.04 & $23.79^{c}$ & 3.82 & $78.00^{* * *}$ \\
\hline C5 & Self-Discipline & $23.38^{\mathrm{a}}$ & 4.28 & $25.53^{\mathrm{b}}$ & 3.99 & $24.10^{\mathrm{c}}$ & 3.95 & $11.70^{* * *}$ \\
\hline C6 & Deliberation & 18.90 & 4.56 & 18.42 & 4.36 & 18.47 & 4.42 & 1.24 \\
\hline
\end{tabular}

${ }^{* * *} p<.001,{ }^{* *} p<.01,{ }^{*} p<.05$; Means with different superscripts are significantly different at $p<.05$ based on Scheffe post-hoc comparisons.

value .03; Wilks Lamda .97; chi square 47.83, dif .3; $p<.001$ Wilks lamda .99) the three varia-bles in the analysis were first Expressed Control (F to remove 27.38), Neuroticism (F14.11) and Wanted Inclusion (F8.39).

Thus what distinguished the Leaders most was the fact they were stable with high Expressed Control, and low Wanted Inclusion.

Table 4 shows the results from a similar analysis this time having the 30 facets as grouping variables. Fourteen variables ended up in the analysis but only the top five were considered. Assertiveness, Trusting, less Altruistic, Achievement Striving and Open to Ideas. 
Table 3. Discriminant Analysis for all three questionnaires entered together.

\begin{tabular}{ccccccccc}
\hline & & & \multicolumn{3}{c}{ Exact F } \\
\hline & Tolerance & F to Remove & Wilks' Lambda & Statistic & Df1 & Df2 & Sig. \\
\hline FIRO-EC & .902 & 59.71 & .973 & 66.77 & 1 & 970.000 & .000 \\
FIRO-WC & .885 & 9.04 & .925 & 37.80 & 2 & 969.000 & .000 \\
NEO-E & .848 & 6.41 & .922 & .921 & 27.69 & 3 & 968.000 & .000 \\
MBTI-JP & .997 & 4.84 & & & & & & \\
Function & Eigenvalue & \% of Variance & Canonical Correlation & Wilks' Lambda & Chi-square & Df & Sig. \\
1 & .091 & 100.0 & .29 & .92 & 84.55 & 4 & .000 \\
\hline
\end{tabular}

Table 4. Discriminant factor analyses for the 30 facets of the NEO-PIR.

\begin{tabular}{|c|c|c|c|c|c|c|c|c|}
\hline \multirow[b]{2}{*}{ Step } & & \multirow[b]{2}{*}{ Tolerance } & \multirow[b]{2}{*}{ F to Remove } & \multirow[b]{2}{*}{ Wilks’ Lambda } & \multicolumn{4}{|c|}{ Exact $\mathrm{F}$} \\
\hline & & & & & Statistic & Df1 & Df2 & Sig. \\
\hline 1 & NEO-E3 & .589 & 42.42 & .878 & 133.530 & 2 & 4002.000 & .000 \\
\hline 2 & NEO-A1 & .752 & 63.44 & .887 & 81.177 & 4 & 8002.000 & .000 \\
\hline 3 & NEO-A3 & .535 & 9.505 & .864 & 69.314 & 6 & 8000.000 & .000 \\
\hline 4 & NEO-C4 & .479 & 14.55 & .866 & 57.652 & 8 & 7998.000 & .000 \\
\hline 5 & NEO-O5 & .912 & 14.48 & .866 & 49.416 & 10 & 7996.000 & .000 \\
\hline 6 & NEO-A6 & .774 & 4.48 & .861 & 42.691 & 12 & 7994.000 & .000 \\
\hline 7 & NEO-C2 & .696 & 5.43 & .862 & 37.823 & 14 & 7992.000 & .000 \\
\hline 8 & NEO-C3 & .557 & 15.63 & .866 & 34.642 & 16 & 7990.000 & .000 \\
\hline 9 & NEO-E6 & .598 & 6.93 & .862 & 31.802 & 18 & 7988.000 & .000 \\
\hline 10 & NEO-A2 & .744 & 6.64 & .862 & 29.228 & 20 & 7986.000 & .000 \\
\hline 11 & NEO-C5 & .469 & 9.32 & .863 & 27.131 & 22 & 7984.000 & .000 \\
\hline 12 & NEO-N1 & .804 & 6.18 & .862 & 25.338 & 24 & 7982.000 & .000 \\
\hline 13 & NEO-E4 & .556 & 5.19 & .862 & 23.742 & 26 & 7980.000 & .000 \\
\hline \multirow[t]{4}{*}{14} & NEO-E1 & .483 & 4.90 & .862 & 22.418 & 28 & 7978.000 & .000 \\
\hline & Function & Eigenvalue & $\%$ of Variance & $\begin{array}{l}\text { Canonical } \\
\text { Correlation }\end{array}$ & $\begin{array}{l}\text { Wilks' } \\
\text { Lambda }\end{array}$ & Chi-square & Df & Sig. \\
\hline & 1 & $.157 \mathrm{a}$ & 96.4 & .368 & .859 & 605.217 & 28 & .000 \\
\hline & 2 & $.006 a$ & 3.6 & .076 & .994 & 23.166 & 13 & .040 \\
\hline
\end{tabular}

This analysis was repeated for each group of five sets of six facets. A clear pattern emerged showing the most differen-tiating and discriminating for each section. For Neuroticism it was N6 Vulnerability (F to remove 54.24); for Extraversion E3 Assertiveness (F to remove 133.53); Agreeableness A1 Trust (F to remove 40.65); for Conscientiousness C4 Achievement Striving (F to remove 77.41).

\section{Discussion}

This study examined personality differences in managers at different levels. It showed on all three measures a range of pre-dicted differences based on the literature. It was based on the assumption that in adulthood personality trait (temperament) changes are very small therefore by doing cross-sectional work it is possible to argue that certain personality traits are associated with promotion or selection for senior positions. These traits possible influence both the choice of job and ambition for advancement as well as how people are seen by others who may be involved in the promotion of individuals. It does however not however necessarily imply that those traits are associated with successful management or leadership at high levels. 
It is of course possible to argue that jobs change personality and that whilst people may choose or get chosen for jobs they in turn are changed by the experience of doing those jobs. There is however very little evidence of the latter being the case. Certainly potential leaders have to learn different behaviouralreper-toires as they change jobs to fulfil various criteria. Hence one finds "socialized" Extraverts who are basically Introverts who learn to behave like Extraverts or trained Agreeable types who learn the script and skills of dealing with poor performance and giving negative feedback (Furnham, 2008b).

There is considerable evidence to show that personality traits are related to a wide array of work related variables from absenteeism and accidents to salaries and sacking (Furnham, 2008b). This study tested ten hypotheses based on the literature six of which were confirmed. This nicely replicates the work of Judge et al. (1999). Leaders need to be Stable because they need to be easily and naturally able to cope with the stress of the job. They would not cope well if they felt Vulnerable, Anxious, Depressed or lacking in Self-confidence. Leadership jobs are often stressful and that those prone to stress (i.e. Neurotic) would cope less well. Thus Neurotics are less likely to seek out leadership positions or be appointed to them (Howard \& Howard, 2001).

Senior Managers tend to be more Extraverted possibly for three reasons (Hogan, 2006; Howard \& Howard, 2001). First, leadership is to a large extent a very interpersonal job spent in meetings, persuading, negotiating etc. Second, Extraverts tend to be more socially skilled with higher emotional intelligence as they have learnt these skills because they have long sought out people as a source of stimulation. Extraverts have more energy and tend to be more socially assertive. Third, Extraversion is associated with optimism, positive emotions and subjective well-being which tends to be attractive to followers.

Senior managers are also more tough minded less modest and compliant because business often requires this of individuals (Howard \& Howard, 2001). Interestingly, the facet analysis suggested seniority was associated positively with Trust but negatively with all the other facets. That is, they tend not to be cynical and sceptical but disagreeable in the tough no-nonsense approach.

Leadership is also inevitably associated with being Conscientious particularly the achievement striving facet. Seniority is associated with competence, hard work and perseverance (Hogan, 2006; Howard \& Howard, 2001).

The FIRO-B scale also yielded interesting and predictable findings. Furnham (2008b) found people with high Expressed control tended to be risk-taking, creative, self-confident and bright. The findings showed clearly the most differentiating of the dimensions was Control where Senior Managers have high Ex-pressed and average Wanted scales. The clinical manual de-scribes those types as "Self Confident" (Ryan, 1977) "They neither avoid making decisions as do persons with extremely low expressed scores, nor do they become overbearing in their control of others, as is the case with persons having extremely high expressed scores. A need for recognition exists along with a high level of aspiration but they are not prone to over extend themselves in a frantic effort to obtain these ends. They respect the limits of reality and work within the realm of their abilities. They seldom over estimate their ability and are not plagued by excessive doubt. When confronted with responsibility their basic stance is, 'If I can do it, I will. Meanwhile stay off my back and let me show you what I can do'.” (p. 616). This is considered a healthy pattern and predictive of success.

The second of the three dimensions that yielded differences were that of Inclusion. Leaders clearly express a greater need for inclusion than they actually want. The clinical manual calls this pattern "Social Flexibility" (Ryan, 1977). "Persons with moderate expressed and moderate wanted inclusion scores not only reveal a moderate level of social interactions but also manifest flexibility. These persons tend to be comfortable both in large groups or being alone, whenever these situations occur. They lack the compulsive urge to move either toward or away from people manifested by the 'People Gatherer' or the 'Loner'. In addition they reveal little concern over rejection or being accepted by others” (p. 14).

The MBTI showed senior managers were NTPs types. It was however the Thinking-Feeling dimension which most differentiated Managers from Non-Managers. This has been established in various other studies using the MBTI (Moutafi et al., 2007). That is that the NT individuals are most usually successful in business (Furnham \& Stringfield, 1993; Rahim, 1981). It is interesting to note that Extraversion-Introversion using this measure did not differentiate senior managers while it clearly did on the NEO-PI-R.

Perhaps the most interesting part of the analysis was however the discriminant analysis. Table 3 shows that when the domain factors were entered, four were best discriminators of Leader-ship; two from the FIRO-B and one from each of the other questionnaires. It was Expressed Control from the FIRO-B that proved by far the most powerful differentiator. Indeed the test was designed so that this dimension predicted specific leadership behaviour. A high Expressed score indicates that a person can and does take on the responsibilities involved in 
the leadership role, while a low wanted Control score means that they do not want to be controlled by others.

The discriminant analysis of all thirty facets and each facet group one at a time showed interesting and interpretable findings. The top five discriminatory facets proved to be Assertiveness (high), Trust (high), Altruism (low), Achievement Striving (high) and Ideas (high). The analysis of the six facets of each of the Big Five domains alone indicated that few of six facets for Extraversion, Agreeableness and Conscientiousness differentiated between the different management groups.

This study has various limitations. Inevitably managerial level and holding a leadership role is a function of many factors such as intelligence, company size and growth, age and experience of the person, organisational culture and policies as well as their personality. As this study had over 5000 managers and business leaders from many different companies it was assumed that none of these factors systematically accounted for the promotion of the manager. However it would be important to examine the effects of some of these factors, with personality traits, on promotability. Second, this was a correlation not longitudinal study hence cause cannot be inferred. Third, it would have been very desirable to have other individual data particularly the intelligence scores of the participants to see the effect of ability on promotability. Other possibly confounding factors that would have been desirable to control for include the age, education and job history of the individuals as well as which sector they worked in. Finally, it would be most desirable to have some equivalent measure (behaviours or ratings) of job performance so that this could be related to the trait measures.

\section{References}

Ahmetoglu, G., Chamorro-Premuzic, T., \& Furnham, A. (2010). Interpersonal Relationship Orientations, Leadership, and Managerial Level. International Journal of Selection and Assessment, 18, 220-225. http://dx.doi.org/10.1111/j.1468-2389.2010.00504.x

Arvey, R. D., Rotendo, M., Johnson, W., Zhang, Z., \& McGue, M. (2006). The determinants of Leadership Role Occupancy. Leadership Quarterly, 17, 1-20. http://dx.doi.org/10.1016/j.leaqua.2005.10.009

Barrick, M. R., \& Mount, M. K. (1991). The Big Five Personality Dimensions and Job Performance: A Meta Analysis. Personnel Psychology, 44, 1-26. http://dx.doi.org/10.1111/j.1744-6570.1991.tb00688.x

Barrick, M. R., \& Mount, M. K. (1993). Autonomy as a Moderator of the Relationships between the Big Five Personality Dimensions and Job Performance. Journal of Applied Psychology, 78, 111-118. http://dx.doi.org/10.1037/0021-9010.78.1.111

Carlson, J. (1985). Recent Assessment of the Myers Briggs Type Indicator. Journal of Personality Assessment, 49, $356-365$. http://dx.doi.org/10.1207/s15327752jpa4904_3

Caspi, A., Elder, G., \& Bem, D. (1987). Moving against the World: Life Course Patterns of Explosive Children. Developmental Psychology, 23, 308-311. http://dx.doi.org/10.1037/0012-1649.23.2.308

Costa Jr., P., \& McCrae, R. (1992). Revised NEO Personality Inventory (NEO-PI-R) and NEO Five-Factor Inventory (NEO-FFI): Professional Manual. Odessa: Psychological Assessment Resources.

Costa, P., \& McCrae, R. (2004). Set Like Plaster? Evidence for the Stability of Adult Personality. In T. Heatherton, \& J. Weinberger (Eds). Can Personality Change? (pp. 21-40). Washington DC: APA.

Dancer, L., \& Woods, S. (2006). Higher-Order Factor Structure and Intercorrelations of the 16PFS and the FIRO-B. International Journal of Selection and Assessment, 14, 385-391. http://dx.doi.org/10.1111/j.1468-2389.2006.00360.x

Furnham, A. (2008a). Psychometric Correlates of FIRO-B Scores: Locating Three FIRO-B Scores in Personality Factor Space. International Journal of Selection and Assessment, 16, 30-45. http://dx.doi.org/10.1111/j.1468-2389.2008.00407.x

Furnham, A. (2008b). Personality and Intelligence at Work. London: Routledge. http://dx.doi.org/10.4324/9780203938911

Furnham, A., \& Stringfield, P. (1993). Personality and Work Performance: Myers-Briggs Type Indicator Correlates of Managerial Performance in Two Cultures. Personality and Individual Differences, 14, 145-153.

http://dx.doi.org/10.1016/0191-8869(93)90184-5

Furnham, A., Crump, J., \& Chamorro-Premuzic, T. (2007). Mangerial Level, Personality and Intelligence. Journal of Managerial Psychology, 22, 805-818. http://dx.doi.org/10.1108/02683940710837732

Harrell, T. W. (1969). The Personality of High Earning MBA’s in Big Business. Personnel Psychology, 22, 457-463. http://dx.doi.org/10.1111/j.1744-6570.1969.tb00346.x

Henderson, J., \& Nutt, P. (1980). The Influence of Decision Style on Decision Making Behaviour. Management Science, 26, 371-386. http://dx.doi.org/10.1287/mnsc.26.4.371

Hogan, R. (2006). Personality and the Fate of Organizations. Mahwah, NJ: Lawrence Erlbaum. 
Hogan, R., \& Hogan, J. (1997). Hogan Development Survey Manual. Tulsa, OK: Hogan Assessment Centres.

Hogan, R., \& Hogan, J. (2001). Assessing Leadership: A View from the Dark Side. International Journal of Selection and Assessment, 9, 40-51. http://dx.doi.org/10.1111/1468-2389.00162

Hough, L. M., Eaton, N. K., Dunnette, M. D., Kamp, J. D., \& McCloy, R. A. (1990). Criterion Related Validities of Personality Constructs and the Effect of the Response Distortion on Those Validities. Journal of Applied Psychology, 75, 581595. http://dx.doi.org/10.1037/0021-9010.75.5.581

Howard, A., \& Bray, D. W. (1994). Predictions of Managerial Success over Time. Lessons from the Management Progress study. In K. E. Clark, \& M. B. Clark (Eds.), Measures of Leadership (pp. 113-130). West Orange, NJ: Leadership Library of America.

Howard, P., \& Howard, J. (2001). The Owner's Manual for Personality at Work. Austin, TX: Bard Press.

Jones, R., \& Whitemore, M. (1995). Evaluating Developmental Assessment Centres as Interventions. Personnel Psychology, 48, 377-383. http://dx.doi.org/10.1111/j.1744-6570.1995.tb01762.x

Judge, T. A., Bono, J. E., \& Locke, E. A. (2000). Personalilty and Job Satisfaction: The Mediating Role of Job Characteristics. Journal of Applied Psychology, 85, 237-249. http://dx.doi.org/10.1037/0021-9010.85.2.237

Judge, T. A., Higgins, C. A., Thorenson, C. J., \& Barrick, M. R. (1999). The Big Five Personality Traits, General Mental Ability and Career Success across the Life Span. Personnel Psychology, 52, 621-652. http://dx.doi.org/10.1111/j.1744-6570.1999.tb00174.x

Judge, T., Bono, J., Ilies, R., \& Gerhert, M. (2002). Personality and Leadership: A Qualitative and Quantitative Review. Journal of Applied Psychology, 87, 765-780. http://dx.doi.org/10.1037/0021-9010.87.4.765

Leigh, V., Cook, M., Kendall, E., \& McHenry, R. (1997). UK Standardisation of the FIRO-B. Oxford Psychometric Forum, Technical Report 2.

Melamed, T. (1996). Validation of a Stage Model of Career Success. Applied Psychology, 45, 35-65. http://dx.doi.org/10.1111/j.1464-0597.1996.tb00848.x

Moutafi, J., Furnham, A., \& Crump, J. (2007). Is Management Level Related to Personality? British Journal of Management, 18, 272-280. http://dx.doi.org/10.1111/j.1467-8551.2007.00511.x

Mumford, T., Campion, M., \& Morgeson, F. (2007). The Leadership Skills Strataplex: Leadership Skill Requirements across Organizational Levels. Leadership Quarterly, 18, 154-166.

http://dx.doi.org/10.1016/j.leaqua.2007.01.005

Myers, I., \& McCaulley, M. (1985). Manual: A Guide to the Development and Use of the Myers-Briggs Type Indicator. Palo Alto, CA: Consulting Psychologists.

Orpen, C. (1983). The Development of Validation of an Adjective Checklist Measure of Managerial Need for Achievement. Psychology, 20, 38-42.

Rahim, A. (1981). Job Satisfaction as a Function of Personality Job Congruence: A Study with Jungian Psychological Types. Psychological Reports, 49, 496-498. http://dx.doi.org/10.2466/pr0.1981.49.2.496

Rawls, D. J., \& Rawls, J. R. (1968). Personality Characteristics and Personal History Data of Successful and Less Successful Executives. Psychological Reports, 23, 1032-1034. http://dx.doi.org/10.2466/pr0.1968.23.3f.1032

Rice Jr., G. H., \& Lindecamp, D. P. (1989). Personality Types and Business Success of Small Retailers. Journal of Occupational Psychology, 62, 177-182. http://dx.doi.org/10.1111/j.2044-8325.1989.tb00488.x

Ryan, L. (1977). Clinical Interpretation of the FIRO-B. Palo Alto, CA: Consulting Psychologist Press.

Salgado, J. (1997). The Five Factor Model of Personality and Job Performance in the European Community. Journal of Applied Psychology, 82, 30-43. http://dx.doi.org/10.1037/0021-9010.82.1.30

Schutz, W. (1958). FIRO: A Three Dimensional Theory of Interpersonal Behaviour. Oxford: Rinehart.

Schutz, W. (1992). Beyond FIRO-B-Three New Theory-Derived Measures-Element B: Behavior, Element F: Feelings, Element S: Self. Psychological Reports, 70, 915-937. http://dx.doi.org/10.2466/pr0.1992.70.3.915

Spector, P. E., Schneider, J. R., Vance, C. A., \& Hezlett, S. A. (2000). The Relation of Cognitive Ability and Personality Traits to Assessment Center Performance. Journal of Applied Social Psychology, 30, 1474-1491. http://dx.doi.org/10.1111/j.1559-1816.2000.tb02531.x

Tornow, W., \& Pinto, P. (1976). The Development of a Managerial Job Taxonomy: A System for Describing, Classifying, and Evaluating Executive Positions. Journal of Applied Psychology, 61, 410-418.

http://dx.doi.org/10.1037/0021-9010.61.4.410

Young, M. S., \& Schinka, J. A. (2001). Research Validity of the NEO-PI-R: Additional Evidence for Reliability and Validity. Journal of Personality Assessment, 76, 412-420. http://dx.doi.org/10.1207/S15327752JPA7603_04 